\title{
PENYULUHAN DAN PEMERIKSAAN GIGI DAN MULUT DI SDN I SIDOSARI LAMPUNG SELATAN
}

\author{
Arianto $^{1}$, Ratnasari $^{1}$, Desi Andriyani ${ }^{*}$, Lies Elina ${ }^{1}$ \\ Dosen Jurusan Keperawatan Gigi Poltekkes Tanjungkarang \\ Jl. Raya Hajimena KM. 14 No. 100 Natar Lampung Selatan \\ Penulis Korespodensi : andriyanidesi@gmail.com
}

\begin{abstract}
Abstrak
Upaya - upaya promosi kesehatan dan pemberdayaan masyarakat sudah dilakukan dalam rangka perubahan perilaku masyarakat menuju Perilaku Hidup Bersih dan Sehat. Perilaku Hidup Bersih dan Sehat merupakan sekumpulan perilaku yang dipraktikkan atas dasar kesadaran sebagai hasil dari pembelajaran yang menjadikan seseorang dapat menolong diri sendiri di bidang kesehatan dan perperan aktif dalam mewujudkan kesehatan masyarakatnya.Kesehatan gigi dan mulut merupakan bagian integral dari pelayanan kesehatan secara keseluruhan. Kesehatan gigi juga merupakan salah satu komponen kesehatan secara menyeluruh dan tidak dapat diabaikan terutama pada tingkat sekolah dasar. Tujuan kegiatan ini melakukan penyuluhan kepada masyarakat khususnya anak sekolah dasar tentang menjaga kesehatan gigi dan mulut,mencegah penyakit gigi dan mulut,melakukan pemeriksaan kesehatan gigi dan mulut.Berdasarkan hasil penelitian diketahui bahwa derajat kesehatan gigi dan mulut anak usia sekolah masih tinggi. Hal ini terlihat dari nilai OHIS 2,3 dan DMFT rata rata 3,4 (buruk), dari desa sidosari 14,3\% terdapat masalah kesehatan gigi dan $86,3 \%$ tidak menerima perawatan gigi.
\end{abstract}

Kata kunci: Kesehatan gigi, Anak $S D$

\section{Pendahuluan}

Menanamkan Perilaku Hidup Bersih dan Sehat kepada setiap orang bukanlah hal yang mudah, akan tetapi memerlukan waktu dan proses yang panjang. Setiap orang hidup dalam tatanannya dan saling mempengaruhi serta berinteraksi antar pribadi dalam tatanan tersebut. Memantau, menilai, dan mengukur tingkat kemajuan tatanan adalah lebih mudah dibandingkan dengan perorangan, oleh karena itu pembinaan Perilaku Hidup Bersih dan Sehat dilakukan melalui pendekatan tatanan, diantaranya sekolah.

Kesehatan gigi dan mulut merupakan bagian integral dari pelayanan kesehatan secara keseluruhan. Kesehatan gigi juga merupakan salah satu komponen kesehatan secara menyeluruh dan tidak dapat diabaikan terutama pada tingkat sekolah dasar (Depkes RI, 2004).

Munculnya beberapa penyakit yang sering menyerang anak usia sekolah umumnya berkaitan dengan kebiasaan hidup bersih ini, maka dirasakan tepat bila memulai menanamkan perilaku hidup bersih dan sehat ini sedini mungkin. Seperti penyakit gigi, lubang gigi disebabkan oleh kebersihan dari gigi dan mulutnya, dimana penyakit gigi dan mulut masuk dalam 10 penyakit terbanyak yang diderita masyarakat Indonesia.

Karies gigi adalah penyakit jaringan keras gigi yang ditandai dengan kerusakan jaringan, dimulai dari permukaan gigi (ceruk, fisura, dan daerah interproximal) yang meluas ke arah pulpa. (Tarigan,2013 ).Karies gigi adalah suatu penyakit jaringan keras gigi yaitu,email,dentin,cementum yang disebabkan oleh aktifitas jasad renik dalam suatu karbohidrat yang diragikan.(Edwiana AM Kidd,dkk , 1992)

Pada tahap awal, kerusakan dimulai pada lapisan terluar gigi (email gigi), karies pada tahap ini disebut karies awal. Bila pada tahap ini karies dibiarkan tanpa perawatan proses akan berlanjut ke bagian lapisan yang lebih dalam, sehingga menyerang lapisan dentin, tahap ini disebut karies agak lanjut. Bila keadaan ini tetap dibiarkan, maka proses karies akan terus berlanjut, sehingga menyerang pulpa dan akan merusak jaringan pulpa atau syaraf gigi, tahap ini disebut karies lanjut.

Anak Sekolah Dasar merupakan kelompok rentan terhadap penyakit gigi dan mulut, sehingga untuk meningkatkan derajat kesehatan gigi dan mulut yang optimal guna untuk mencegah 
terjadinya penyakit gigi dan mulut maka perlu diadakan suatu kegiatan pelayanan asuhan kesehatan gigi dan mulut (Depkes, 1995)

Berdasarkan rekesdas 2013, bahwa masyarakat belum menyadari pentingnya pemeliharaan kesehatan gigi dan mulut. Hal ini terlihat dari $22,8 \%$ penduduk tidak menyikat gigi dengan benar. Tetapi dari 77,2 \% yang menyikat gigi hanya $8,1 \%$ yang menyikat gigi dengan benar dan tepat waktu. Berdasarkan hasil penelitian diketahui bahwa derajat kesehatan gigi dan mulut anak usia sekolah masih tinggi.

Program Pelayanan Asuhan Kesehatan Gigi dan Mulut, diantaranya Pendidikan dan Pengajaran dengan memberikan penyuluhan kesehatan gigi dan mulut,program sikat gigi bersama, pemeriksaan gigi dan melaksanakan tindakan kuratif sederhana.

Untuk menilai status kesehatan gigi dan mulut dalam hal ini karies gigi tetap digunakan nilai DMF-T (Decay Missing Filled Teeth). Angka D (decay) adalah jumlah gigi berlubang karena karies gigi, angka $\mathbf{M}$ (missing) adalah gigi yang dicabut karena karies gigi, angka $F$ (filled) adalah gigi yang ditambal atau ditumpat karena karies dan dalam keadaan baik pada seseorang. Menurut WHO, indicator utama pengukuran DMF-T adalah anak usia 12 tahun yaitu $\leq 3$, yang artinya pada usia 12 tahun jumlah gigi yang berlubang (D), dicabut karena karies gigi (M), dan gigi dengan tumpatan yang baik $(\mathrm{F})$, adalah 3 ( tiga) gigi per anak.

Menilai status kesehatan gigi dan mulut dalam hal ini karies gigi susu/decidui digunakan nilai def-t (decay exoliasi filled teeth). Angka d (decay) adalah jumlah gigi berlubang karena karies gigi, angka e (exoliasi) adalah gigi yang dicabut karena karies gigi, gigi persistensi dan sisa akar, angka $f$ (filled) adalah gigi yang ditambal atau ditumpat karena karies dan dalam keadaan baik pada seseorang.Menurut WHO, indicator utama pengukuran def-t adalah anak usia $<12$ tahun yaitu $\leq 3$, yang artinya pada usia $<12$ tahun jumlah gigi yang berlubang (d), dicabut karena karies gigi, gigi persistensi dan sisa akar (e), dan gigi dengan tumpatan yang baik (f), adalah 3 ( tiga) gigi per anak. Sesuai dengan tinggi rendahnya tingkat karies gigi menurut WHO yaitu : Sangat Rendah : 0,0 - 1,1. Rendah : 1,2-2,6. Sedang : 2,7 -4,4.Tinggi 4,5-6,6. Sangat tinggi : 6,6- lebih.

\section{Bahan dan Metode}

A. Alat dan Bahan yang digunakan satpel,famflet,alat pemeriksaan ( OD ),kartu pemeriksaan, Sikat gigi,pasta gigi.

\section{B. Metode yang digunakan dalam pelaksanaan pengabdian masyarakat \\ dengan strategi Pra Pelaksanaan : membuat} TOR dan proposal, rapat sosialisasi dengan tim dan melakukan pra survey lapangan untuk menentukan rencana kegiatan serta penyediaan sarana prasarana. Pelaksanaan : Tahap pelaksanaan dibagi dua :

a.Pemeriksaan Kesehatan Gigi : DMF-T dan def-t .di SDN Sidosari Kecamatan Natar Kabupaten Lampung.

b. Pemeliharaan Kesehatan Gigi

(penyuluhan, Sikat gigi bersama) di SDN Sidosari Kecamatan Natar Kabupaten Lampung.

\section{Hasil dan Pembahasan}

Kegiatan pengabdian masyarakat Jurusan Keperawatan gigi pada masyarakat Khususnya di SDN Sidosari Kecamatan Natar Kabupaten Lampung Selatan dalam bentuk pemeriksaan kesehatan gigi dan mulut, pemeliharaan kesehatan gigi dan mulut, Pihak sekolahan merespon dengan baik, dimana siswa-siswi dapat diperiksa kesehatan gigi dan mulut dan mau diberikan penyuluhan kesehatan gigi dan mulut sesuai dengan waktu yang direncanakan (terlampir pada foto kegiatan), sedangkan untuk hasil pemeriksaan kesehatan gigi dan mulut di SDN Sidosari Kecamatan Natar Kabupaten Lampung Selatan , def-t dan DMFT sebagai berikut:

Tabel 1. Hasil pemeriksaan kesehatan gigi dan mulut berdasarkan jenis kelamin (def-t)

\begin{tabular}{|l|l|l|l|l|l|l|l|}
\hline J.K & S.T & T & S & R & S.R & S & \\
\hline L & 16 & 14 & 14 & 3 & 3 & 6 & \\
\hline P & 19 & 16 & 9 & 4 & 2 & 5 & \\
\hline
\end{tabular}

J.k : Jenis Kelamin

S.T : Sangat Tinggi

$\mathrm{T}$ : Tinggi

$\mathrm{S}$ : Sedang

$\mathrm{R}$ : Rendah

S.R : Sangat Rendah

$S$ : Sehat

Berdasarkan jenis kelamin perempuan rata rata def-t tinggi terlihat bahwa dari 55 yang diperiksa 19 orang $(35,5 \%)$ def-t sangat tinggi, 16 orang $(29,1 \%)$ def-t Tinggi, 9 orang $(16,4 \%)$ def- 
t sedang, 4 orang $(7,3 \%)$ def-t rendah, 2 orang ( $3,6 \%$ ) def-t sangat rendah, dan 5 orang $(9,1 \%)$ def-t sehat. Sedangkan untuk nilai DMF-T rata rata sangat rendah terlihat dari 55 yang diperiksa 0 orang $(0 \%)$ DMF-T sangat tinggi, 0 orang $(0 \%)$ DMF-T Tinggi, ,4 orang (7,3\%) DMF-T sedang, 6 orang $(10,9 \%)$ DMF-T rendah, 8 orang $(14,5 \%$ ) DMF-T sangat rendah, dan 37 orang $(67,3 \%)$ DMF-T sehat.

Berdasarkan jenis kelamin laki laki yang diperiksa rata rata tinggi terlihat bahwa dari 56 yang diperiksa 16 orang $(28,5 \%)$ def-t sangat tinggi, 14 orang $(25 \%)$ def-t Tinggi, 14 orang (25\%) def-t sedang, 3 orang ( 5,4\%) def-t rendah, 3 orang $(5,4 \%)$ def-t sangat rendah, dan 6 orang $(10,7 \%$ ) def-t sehat. Sedangkan nilai DMF-T rata rata sangat rendah. Terlihat dari 56 yang diperiksa 0 orang $(0 \%)$ DMF-T sangat tinggi, 0 orang $(0 \%)$ DMF-T Tinggi, ,2 orang (3,6 \%) DMF-T sedang, 9 orang $(16,1 \%)$ DMF-T rendah, 10 orang $(17,8$ $\%$ ) DMF-T sangat rendah, dan 35 orang (62,5\% ) DMF-T sehat.

\section{Kesimpulan}

Kegiatan pengabdian masyarakat Jurusan Keperawatan gigi pada masyarakat Khususnya di SDN Sidosari Kecamatan Natar Kabupaten Lampung Selatan dalam bentuk pemeriksaan kesehatan gigi dan mulut, pemeliharaan kesehatan gigi dan mulut, Pihak sekolahan merespon dengan baik, dimana siswa-siswi dapat diperiksa kesehatan gigi dan mulut dan mau diberikan penyuluhan kesehatan gigi dan mulut sesuai dengan waktu yang direncanakan. Jumlah siswa yang dilakukan pemeriksaan dan penyuluhan 56 siswa .hasil pemeriksaan.berdasarkan jenis kelamin laki laki yang diperiksa rata rata sangat tinggi terlihat bahwa dari 56 yang diperiksa 16 orang $(28,5 \%)$ def-t sangat tinggi, 14 orang $(25 \%)$ def-t Tinggi, 14 orang $(25 \%)$ def-t sedang, 3 orang ( $5,4 \%)$ def-t rendah, 3 orang $(5,4 \%)$ def-t sangat rendah, dan 6 orang ( $10,7 \%)$ def-t sehat. Sedangkan nilai DMF-T rata rata sangat rendah.
Terlihat dari 56 yang diperiksa 0 orang (0\%) DMF$\mathrm{T}$ sangat tinggi, 0 orang (0\%) DMF-T Tinggi, ,2 orang $(3,6 \%)$ DMF-T sedang, 9 orang ( $16,1 \%)$ DMF-T rendah, 10 orang ( $17,8 \%)$ DMF-T sangat rendah, dan 35 orang $(62,5 \%)$ DMF-T sehat.

Tabel 2. Hasil pemeriksaan kesehatan gigi dan mulut berdasarkan jenis kelamin (DMF-T)

\begin{tabular}{|l|l|l|l|l|l|l|}
\hline J.K & S.T & T & S & R & S.R & S \\
\hline L & 0 & 0 & 2 & 9 & 10 & 35 \\
\hline P & 0 & 0 & 4 & 6 & 8 & 37 \\
\hline
\end{tabular}

J.k : Jenis Kelamin

S.T : Sangat Tinggi

$\mathrm{T}$ : Tinggi

$S$ : Sedang

$\mathrm{R}$ : Rendah

S.R : Sangat Rendah

$S$ : Sehat

\section{Ucapan Terima Kasih}

1. Bapak Warjidin Aliyanto, SKM.M.Kes selaku Direktur Poltekkes Tanjungkarang.

2. Bapak Kodri,SKP.M.Kes selaku Wakil Direktur 1 Poltekkes Tanjungkarang.

3. Bapak Haris Kadarusman,SKM.M.Kes selaku Kepala Unit PPM Poltekkes Tanjungkarang.

4. Bapak Bustan S.Ag Selaku Kepala sekolah SDN Sidosari Kecamatan Natar Kabupaten Lampung Selatan

5. Semua pihak yang tidak bisa disebutkan satu persatu.

Kami sadari dalam penyusunan proposal ini masih banyak terjadi kekurangan, oleh karena itu saran sangat kami harapkan demi perbaikan selanjutnya.

\section{Daftar Pustaka}

Depkes RI; 2013. Laporan Nasional Riset Kesehatan Dasar Tahun 2013. Badan Penelitian dan pengembangan Kesehatan

Data survey kesehatan 2016, Poltekkes Tanjungkarang 